\title{
SEKILAS TENTANG TAFSIR WAHBAH AL-ZUHAILY
}

Oleh: Muhammad Hambali, M.Th.I. emuhammadhambali@gmail.com

\section{Absrak}

$$
\text { STIQ Wali Songo }
$$

Berbicara tentang penafsir al-Qur'an tidaklah akan terlepas dari membicarakan para mufassir ataupun penulis kitab-kitab tafsir terdahulu. Hal itu karena para mufassir masa kini merupakan penerus mufassir sebelumnya. Kalaulah ulama' itu pewaris para Nabi dan salah satu tugas Nabi adalah menjelaskan maksud al-Qur'an maka wajarlah sejak awal ulama' itu mengerahkan tenaga untuk melestarikan tafsir al-Qur'an demi kemaslahatan umat sebagai problem solving hari ini maupun di masa yang akan datang. Salah satu ulama' masa kini yang turut mengerahkan tenaga dalam melestarikan tafsir al-Qur'an adalah Wahbah bin Mushtafa al-Zuhaily. Ia telah berhasil membuahkan karya tafsir yang tidak mudah rasanya dicapai oleh kebanyakan orang. Cendikiawan asal Suriah itu telah meninggalkan kitab tafsir berjilid-jilid dengan uraian-uraian yang begitu padat. Tidak berlebihan kiranya kalau penulis katakan bahwa buah karya Wahbah bin Mushtafa al-Zuhaily merupakan "emas" yang sangat berharga dalam dunia ilmu alQur'an dan tafsir.

Artikel ini membahas Wahbah bin Mushtafa al-Zuhaily berikut kitab tafsirnya. Penulis berupaya mengenalkan kepada pembaca tentang metode Wahbah bin Mushtafa al-Zuhaily dalam menulis tafsirnya. Walaupun pembahasan dalam artikel ini tidaklah begitu detail dan mendalam, namun boleh jadi merupakan diskursus yang cukup segar dalam disiplin ilmu al-Qur'an dan Tafsir.

\section{A. PENDAHULUAN}

Penafsiran terhadap ayat-ayat al-Qur'an bukanlah sesuatu yang baru datang kemudian. Mengingat bahwa penafsiran merupakan upaya menjelaskan maksud dari ayat-ayat al-Qur'an maka sejak awal Nabi Muhammad adalah orang pertama yang bertindak sebagai mufassir ${ }^{1}$.

Semenjak awal turunnya al-Qur'an sampai masa Bani Umayyah, penafsiran al-Qur'an telah mengalami beberapa fase. Husain al-Zahaby melakukan kajian mendalam terhadap fase-fase perkembangan tafsir tersebut. Menurutnya, penafsiran demi penafsiran terhadap ayat-ayat al-Qur'an telah mengalami tiga fase signifikan;

\footnotetext{
${ }^{1}$ di dalam surat an-nahl ayat 44 dan 64 disebutkan bahwa diturunkannya al-Qur'an adalah agar Nabi Muhammad menjelaskan isi yang dikandungnya dan juga memberikan penjelasan dari al-Qur'an terkait persoalan-persoalan agama ataupun hukum yang terkadang masih diperselisihkan oleh manusia.
} 
fase Nabi Muhammad, fase tabi'in, hingga fase $\operatorname{tadwin}^{2}$. Dari sisi lain, hal ini menunjukkan bahwa perhatian ulama' salaf-sebagai penerus Nabi kala itu-terhadap al-Qur'an patut dikagumi.

Fase pertama adalah fase Nabi Muhammad. Fase inilah yang penulis katakan tadi bahwa sejak awal Nabi Muhammad memang bertindak sebagai mufassir ataupun mubayyin (penjelas) kepada kaumnya saat itu. Jikalau untuk memahami al-Qur'an cukup dengan mengerti bahasa arab, bukankah kaum Nabi Muhammad saat itu adalah bangsa yang berbahasa arab bahkan saat itu kesusastraan sudah mencapai puncaknya. Lantas kenapa Nabi Muhammad masih diperintah oleh Tuhan untuk menjelaskan ayat-ayat yang berbahasa arab itu kepada mereka ${ }^{3}$. Lalu kenapa Ibn Abbas yang dikenal sebagai cendikiawan saat itu baru memahami maksud dari "fatirussamawati" setelah mendapati dua orang arab yang bertengkar berebut sebuah sumur ${ }^{4}$. Maka inilah pentingnya sosok Nabi Muhammad yang bertindak sebagai mufassir untuk menjelaskan kehendak Tuhan yang tersirat di dalam ayat-ayat alQur'an. Kalau tidak berlebihan maka penulis katakan bahwa inilah pentingnya ilmu al-Qur'an dan tafsir, bahkan dengan hanya menguasai bahasa arab dirasa belum cukup sempurna untuk memperoleh pemahaman yang komprehensif terhadap alQur'an.

Fase kedua adalah penafsiran pada masa tabi'in' ${ }^{5}$. Nama-nama seperti; Said bin Jabr, Mujahid, 'Ikrimah, Tawush bin Kaisan al-Yamany, 'Ato' bin Aby Rabah adalah beberapa tabi' in yang menjadi rujukan penafsiran al-Qur'an di Makkah saat itu. Sedangkan di Madinah, beberapa tabi'in seperti; Zaid bin Aslam, Abu al-'Aliyah, dan Muhammad bin Ka'b al-Qurzy merupakan rujukan yang dikenal dalam penafsiran al-Qur'an. Tabi' in yang menjadi rujukan di Iraq adalah murid-murid dari Sahabat Ibn Mas'ud yaitu; 'Alqamah bin Qais, Masruq, al-Aswad bin Zaid, Murrah al-Hamdany, 'Amir al-Sya'by, al-Hasan al-Bashry, dan Qatadah.

Fase ketiga adalah fase tadwin. Fase ini bersamaan dengan dimulainya penulisan-penulisan hadis Nabi. Awalnya, para cendikiawan saat itu bukanlah

\footnotetext{
${ }^{2}$ Fase ini menurut Husain al-Zahaby berada pada waktu masa transisi dari pemerintahan Bani Umayyah menuju pemerintahan Abbasiyah. Fase itu merupakan masa subur dunia Islam dalam bidang kepenulisan., al-Zahaby, al-Tafsir wa al-Mufassirun, 1., 104.,

${ }^{3}$ di dalam surat Ibrahim ayat 4 disebutkan bahwa Tuhan tidak mengutus seorang utusan kecuali dengan menggunakan bahasa kaumnya sendiri agara supaya utusan itu memberi penjelasan kepada mereka.

4 al-Zahaby,al-Tafsir wa al-Mufassirun, Cairo: Maktabah Wahbah, 2000., 1., 29.

5 Ibid, 1., 76.
} 
hendak menulis tafsir secara mandiri namun karena mereka menulis hadis Nabi berdasarkan bab per bab maka tafsir al-Qur'an menjadi salah satu darinya. Adanya tulisan terkait tafsir al-Qur'an merupakan bagian dari proyek kepenulisan hadis Nabi saat itu. Beberapa nama yang tercatat sejarah sebagai penulis hadis-hadis yang berkaitan dengan tafsir adalah; Yazid bin Harus al-Silmy (wafat 117 H.), Syu'bah bin al-Hajjaj (wafat 160 H.), Waki' bin al-Jarh (wafat 197 H.), Sufyan bin 'Uyainah (wafat 198 H.), Ruh bin 'Ubadah al-Bashry (wafat 205 H.), 'Abdu al-Razzaq bin Hamam (wafat 211 H.), Adam bin Aby Iyas (wafat 220 H.), Abdu bin Humaid (wafat 249 H.). Mereka adalah nama-nama pemuka hadis pada zamannya, walaupun mereka belum menulis tafsir al-Qur'an secara mandiri namun upaya mereka dalam menulis hadis yang berkaitan dengan tafsir dan menjadikannya menjadi satu bab di antara bab-bab yang lain merupakan celah bagi munculnya karya-karya tafsir selanjutnya.

Tidak terlalu menunggu lama, kemunculan karya tafsir benar-benar telah memperlebar celah itu. Seorang cendikiawan bernama Ibn Majah (wafat 273 H.) telah berhasil membuahkan karya tafsir yang mandiri. Kemudian disusul oleh Ibn Jarir al-Tabary (wafat 310 H.), Abu Bakr al-Munzir al-Naisabury (wafat 318 H.), Ibn Aby Hatim (wafat 327 H.), Abu al-Syaikh bin Hibban (wafat 369 H.), al-Hakim (wafat 405 H.), dan Abu Bakr bin Mardawaih (wafat 410 H.)

Perhatian para cendikiawan terhadap al-Qur'an salah satunya bisa terlihat dari karya mereka yang melimpah dalam bidang tafsir. Hampir semua bidang keilmuan dititikberatkan dalam karya tafsirnya berdasarkan latar belakang keilmuan yang dimiliki masing-masing. Itu sebabnya kenapa setiap karya tafsir memiliki metode yang berbeda-beda dan juga memiliki aliran ataupun corak tersendiri yang mendominasi pembahasannya.

Melimpahnya karya di bidang tafsir telah melampaui tiga fase yang disebutkan oleh Husain al-Zahaby di atas. Seorang cendikiawan setelahnya, Abdu alQadir Muhammad Shalih membukukan hasil penelitiannya dan menamai karyanya itu dengan "al-Tafsir wa al-Mufassirun fi al'Ashr al-Hadith". Melihat dari judulnya saja, mengabarkan bahwa sampai detik ini bahkan sampai masa yang akan datang perhatian dan semangat para cendikiawan terhadap al-Qur'an tidak akan pernah surut. 
Di dalam kitabnya, Abdu al-Qadir Muhammad Shalih menyebutkan tafsirtafsir-salah satunya-yang lahir di era 70an seperti tafsir al-Tahrir wa al-Tanwir karya Muhammad Tahir Ibn 'Asyur. Karya yang lebih baru seperti Tafsir al-Sya'rawy buah karya ulama Mesir yang bernama Muhammad Mutawally al-Sya'rawy (wafat 1998 M). Contoh lain seperti; al-I'jaz al-Bayany fi al-Qur'an karya 'Aisyah bintu Syathi' (wafat 1998 M), Sofwatu al-Tafsir karya Muhammad 'Aly al-Shabuny (wafat 2015 M), al-Tafsir al-Wasith karya Wahbah al-Zuhaily (wafat 2015 M).

Di dalam artikel ini penulis membahas terkait Wahbah al-Zuhaily yang disinggung oleh Muhammad Shalih di atas. Hanya saja Muhammad Shalih-di dalam kitabnya-memfokuskan pembahasan pada karya Wahbah al-Zuhaily yang berjudul al-Tafsir al-Wasith. Bukan berarti ia tidak mengetahui bahwa Wahbah al-Zuhaily memiliki karya tafsir lain yang lebih besar yaitu al-Tafsir al-Munir. Walaupun demikian, upaya Muhammad Shalih telah membuka celah, mendorong dan membantu penulis untuk menelusuri lebih mendalam tentang tafsir besar Wahbah alZuhaily.

\section{B. PEMBAHASAN}

\section{Metode Dan Corak Tafsir}

Seperti yang penulis sebutkan pada pendahuluan bahwa ragamnya aliran/corak kitab tafsir memang karena kemampuan serta kecenderungan yang dimiliki penulisnya berbeda-beda. Sebelum penulis membedah karya seorang Wahbah al-Zuhaily, tidak ada salahnya penulis paparkan tentang pemetaan metode tafsir serta corak atau alirannya sebagaimana ditemukan oleh para pakar ilmu alQur'an dewasa ini.

\section{a) Metode Tafsir}

Penulis tidak menafikan bahwa seorang guru besar Universitas Islam Negeri Sunan Ampel Surabaya, Muhammad Ridlwan Nasir telah melakukan penelitian mendalam terhadap metode-metode penafsiran. Ia memaparkan hasil risetnya itu pada pidato pengukuhan guru besar di Fakultas Syari'ah Universitas Islam Negeri Sunan Ampel tahun 1997 silam. Menurut penulis, hasil riset Muhammad Ridlwan Nasir cukup membantu dan memudahkan 
pelajar untuk memahami ragam metode dan corak penafsiran yang berkembang.

Cara atau metode yang selama ini banyak dipakai oleh para mufassir bisa dikategorisasikan-menurut penulis-menjadi dua metode besar; pertama, al-tafsir bi al-ma'tsur dan kedua, al-tafsir bi al-ra'yi. Tidak sedikit referensi yang membahas kedua metode tersebut. ${ }^{6}$

Al-tafsir bi al-ma'tsur merupakan metode penafsiran klasik yang pertama. Penulis menduga kuat bahwa metode ini merupakan metode yang dianggap paling sohih (sehat) karena semua penafsirannya langsung bersumber dari Nabi Muhammad dan juga beberapa dari para sahabat dan tabi'in. Artinya, seorang mufassir hanya menukil dan menulis kembali riwayat-riwayat penafsiran/penjelasan Nabi ataupun sahabat dan tabi'in yang berkaitan dengan ayat yang sedang dikaji.

Al-tafsir bi al-ra'yi juga merupakan metode penafsiran klasik yang kedua. Metode ini berbasis ijtihad dan pemikiran murni dari seorang mufassir tentunya dengan bekal ilmu kebahasaan dan ilmu-ilmu lain yang membantu dalam memahami maksud dari ayat-ayat al-Qur'an. Metode ini tidak terlepas dari kritik para pakar terkait hasil pemikiran dari seorang mufassir, apakah buah tafsirnya mendekati atau malah menjauhi kebenaran.

Kedua metode itu merupakan pokok, walaupun setelahnya muncul metode ketiga, metode baru yang disebut dengan al-Tafsir bi al-Iqtiran yaitu metode yang memadukan antara kedua metode pokok tersebut. Metode ketiga ini dinamai oleh Muhamad Rasyid Rida dengan istilah "Shahih al-Manqul wa Sharih al-Ma'qul". Namun kemunculan metode ketiga ini hakikatnya tidaklah menyimpang dari kedua metode pokok, ia hanya menggabungkan saja.

Namun untuk mempermudah, penulis mengikuti alur sebagaimana Muhammad Ridlwan Nasir paparkan yaitu ${ }^{7}$ :

\footnotetext{
6 Mahmud al-Naqrasyi al-Sayyid 'Aly, Manahij al-Mufassirin min al- 'Ashr al-Awwal ila al- 'Ashr alHadist, Maktabah al-Nahdlah: 69., Muhammad bin Luthfi al-Shobag, Lamhat fi 'Ulum al-Qur'an wa Ittijahat al-Tafsir, Beirut: al-Maktabah al-Islamy, 1990, 260., Muhammad Husain al-Zahaby, 'Ilm alTafsir, Cairo: Dar al-Ma'arif, t.t., 39.

7 Muhammad Ridlwan Nasir, Teknik Pengembangan Metode Tafsir Muqarin, t.p.: 2997, 5.
} 
Bila ditinjau berdasar faktor dominasi sumber penafsiran, maka metode tafsir ada tiga macam;

a. Metode Tafsir Bi al-Ma'tsur, yaitu tata cara menafsirkan ayatayat al-Qur'an yang didasarkan atas sumber penafsiran alQur'an, dari al-Hadits, dari riwayat sahabat, dan tabi'in.

b. Metode Tafsir Bi al-Ra'yi, yaitu cara menafsirkan ayat-ayat alQur'an yang didasarkan atas sumber ijtihad dan pemikiran mufassir terhadap tuntutan kaidah bahasa Arab dan kesusasteraannya, teori ilmu pengetahuan setelah dia menguasai sumber-sumber tadi.

c. Bil Iqtirani, adalah cara menafsirkan al-Qur'an yang didasarkan atas perpaduan antara sumber tafsir riwayah yang kuat dan shahih dengan sumber hasil ijtihad pikiran yang sehat.

Bila ditinjau dari segi cara penjelasannya terhadap tafsiran ayat-ayat al-Qur'an, maka metode tafsir ada dua macam;

a. Metode Bayani, yaitu penafsiran dengan cara menafsirkan ayat-ayat al-Qur'an hanya dengan memberikan keterangan secara deskripsi tanpa membandingkan riwayat/pendapat dan tanpa menilai (tarjih) antar sumber.

b. Metode Muqarin, yaitu membandingkan ayat dengan ayat yang berbicara dalam masalah yang sama, ayat dengan hadits, antara pendapat mufassir dengan mufassir lain dengan menonjolkan segi-segi perbedaan.

Bila ditinjau dari segi keluasan penjelasan tafsirannya, maka ada dua macam;

a. Metode Ijmaly, yaitu penafsiran dengan cara menafsirkan ayat al-Qur'an hanya secara global saja, tidak mendalam dan panjang lebar.

b. Metode Ithnaby, yaitu penafsiran secara mendetail/rinci, dengan uraian yang panjang. 
Bila ditinjau dari segi sasaran dan tertib ayat-ayat yang ditafsirkan, maka ada dua macam;

a. Metode Tahlily, yaitu menafsirkan ayat-ayat al-Qur'an dengan cara urut dan tertib sesuai dengan urutan ayat-ayat dan suratsurat dalam mushaf al-Qur'an, dari awal surat al-Fatihah sampai dengan akhir surat an-Nas.

b. Metode Maudlu'iy, yaitu suatu penafsiran dengan cara mengumpulkan ayat mengenai satu topik tertentu, dengan memperhatikan masa turunnya dan azbabunnuzulnya, serta mempelajari ayat-ayat tersebut secara cermat dan mendalam, dengan memperhatikan korelasi ayat yang satu dengan lainnya dalam menunjuk suatu permasalahan, kemudian menyimpulkan masalah yang dibahas dari petunjuk ayat-ayat yang ditafsirkan secara terpadu.

\section{b) Corak Tafsir}

Corak tafsir merupakan arah penafsiran yang menjadi kecenderungan penafsirnya. Seperti tafsir yang bercorak kebahasaan dan gramatika bahasa arab karya al-Farra' (Tafsir Musykil I'rab al-Qur'an wa Ma'anihi) dan Abu Hayyan (al-Bahr al-Muhit). Al-Zamakhsyary yang menulis kitab tafsir (alKasysyaf) dengan menonjolkan sastra al-Qur'an. Ada juga tafsir-tafsir lain yang bercorak sufi, hukum fiqih (Tafsir al-Jami' li Ahkam al-Qur'an karya al-Qurthuby), sosial (tafsir al-Manar karya Syaikh Muhammad Abduh dan Syaikh Rasyid Ridla), ada yang bercorak sains/ilmu pengetahuan modern (alJawahir karya Thantawy Jauhary), dan lain sebagainya.

\section{Biografi Wahbah Al-zuhaily}

Ia bernama Wahbah bin Musthafa al-Zuhaily al-Dimasyqy. Ia dilahirkan di Dair Atiah, Damaskus, Suriah pada tahun 1932 M dan wafat pada 8 Agustus 2015 M. Ia tercatat sebagai anak seorang petani yang saleh. ${ }^{8}$

\footnotetext{
${ }^{8}$ Muhammad 'Arif Ahmad Fari', Manhaj Wahbah al-Zuhaily fi Tafsirihi li al-Qur'an "al-Tafsir alMunir”, 16.
} 
Ia menempuh pendidikan dasar di Suriah. Kemudian melanjutkan ke jenjang menengah di Kuliah Syari'ah di Damaskus selama kurang lebih enam tahun. Selanjutnya ia melanjutkan kuliah syari'ahnya ke al-Azhar-Mesir sehingga mendapatkan ijazah Baccalaureus (Bachelor/strata I) dengan nilai yang memuaskan pada sekitar tahun 1956 M. Semangat belajarnya semakin membaik, sehingga ia mengambil takhossus dalam mempelajari bahasa arab di al-Azhar. Licences ia dapatkan pada tahun 1957 dari Kampus 'Ain Syams dengan nilai Jayyid Jiddan dalam bidang ilmu huquq/qanun (undang-undang/syari'ah). Kemudian di bidang itu, ia teruskan jenjangnya hingga mendapat gelar Magister pada tahun 1959 di Kampus al-Azhar. Pada tahun 1963, penelitiannya (al-Uthruhah) yang berjudul "Atsar alHarb fi al-Fiqh al-Islamy; Dirasat Muqaranah Baina al-Mazahib al-Tsamaniyah wa al-Qanun al-Dauly al-'Am” mampu mengantarkannya memperoleh gelar doktor dengan nilai al-Syarf al-Ula dalam bidang Ilmu Syariah. ${ }^{9}$

Dalam perkembangan intelektualnya, ia sedikit banyak mendapat pengaruh dari guru-gurunya baik di Damaskus ataupun di Mesir. Beberapa orang yang pernah menjadi gurunya adalah seperti; Hasan Habnakah al-Maidany, Mahmud Syaltut, dan Muhammad Abu Zahrah, dan tentunya masih banyak lagi yang tidak disebut di sini.

Karier ilmiyahnya dimulai ketika ia menjadi pengajar di Kampus Damaskus (1963) kemudian menjadi pembantu rektor (1969) hingga menjadi professor (1975). Kesibukannya tidak ada lain kecuali mengajarkan ilmu yang menjadi spesialisasinya, yaitu tentang fiqih atau syariah islam. Mengisi kuliah di berbagai tempat dan kesempatan; di kampus Muhammad bin 'Aly al-Sanusy (Libya), kampus al-Imarah (1989-1984), mengisi kuliah di kampus al-Khurtum (Sudan) dan kampus Umm Darman. Mengajarkan ilmu fiqih ke berbagai negara seperti; Pakistan, Sudan, dll.

Karya al-Zuhaily yang disumbangkan kepada khazanah keilmuan Islam terdiri dari berbagai macam disiplin ilmu, seperti; ilmu fiqh, ilmu hadist, sejarah, pendidikan umum, ilmu al-Qur'an dan tafsir.

Karya al-Zuhaily dalam bidang fiqh sangatlah banyak, hal itu karena spesialisasi keilmuannya adalah dalam bidang Syariat. Beberapa dari karyanya dalam bidang fiqih yaitu; Atsar al-Harb fi al-Fiqh al-Islamy, Nazariyyat al-Dlarurat al-

\footnotetext{
9 'Abd al-Qadir Muhammad Salih, al-Tafsir wa al-Mufassirun fi al-'Ashr al-Hadits, Beirut: Dar alMa'rifah, 2003. 205.
} 
Syar'iyyah, Nazariyyat al-Dliman wa Ahkam al-Mas'uliyyat al-Madaniyyah wa alJina'iyyah fi al-Fiqh al-Islamy, al-Nushush al-Fiqhiyyah al-Mukhtarah, Fiqh alMawarits, al- 'Uqubat al-Syar'iyyah wa Asbabuha, Juhud Taqnin al-Fiqh al-Islamy, al-Fiqh al-Islamy 'ala al-Mazhab al-Maliky, Ushul al-Fiqh al-Islamy, al-Wajiz fi Ushul al-Fiqh, al-Fiqh al-Hanbaly al-Muyassar bi Adillatihi wa Tathbiqotihi alMu'ashirah, al-Taqlid fi al-Mazahib al-Islamiyyah, Qowaid al-Fiqh al-Hanbaly, alDlawabidl al-Syar'iyyah li al-Akhzi bi Aisar al-Mazahib, Ahkam al-'Ibadat 'ala alMazhab al-Maliky, al-Fiqh al-Islamy wa Adillatuhu.

Dalam bidang ilmu hadits seperti; Takhrij wa Tahqiq Ahadits Tuhfat alFuqaha' li al-Samarqandy, Takhrij wa Tahqiq Ahadits wa Atsar Jami' al-Ulum wa al-Hukm.

Dalam bidang sejarah; biografi Ubadah bin al-Shamit, biografi Usamah bin Zaid, biografi Said bin al-Musib, Biografi Umar bin Abd al- 'Aziz.

Dalam bidang pendidikan/kebudayaan umum, seperti; Nizam al-Islam, al'Alaqah al-Dauliyyah fi al-Islam, al-Ilm wa al-Iman wa Qadaya al-Syabab, al-Islam Din al-Jihad la al- 'Udwan, al-Muwafadat fi al-Islam, al-Islam Din al-Syura wa alDimiqratiyyah, al-Ulum al-Syar'iyyah baina al-Wahdah wa al-Istiqlal, al-Islam wa al-Iman wa al-Ihsan.

Dalam bidang al-Qur'an, seperti; al-Qur'an al-Karim al-Bunyah alTasyri'iyyah wa al-Khashais al-Hadariyyah, al-Tafsir al-Wajiz, al-Tafsir al-Wasith, al-Qissah al-Qur'aniyyah hidayat wa bayan, dan yang terakhir adalah kitab tafsir yang menjadi objek pembahasan artikel ini.

\section{Tafsir Wahbah Al-Zuhaily}

Al-Zuhaily sebenarnya memiliki tiga kitab tafsir; pertama, adalah Tafsir alWasith sedangkan kedua adalah tafsir yang menjadi objek pembahasan artikel ini dan ketiga adalah Tafsir al-Wajiz. Tafsir pertama terdiri dari tiga jilid, lebih ringkas dari tafsir kedua. Tafsir al-Wasith menyuguhkan penjelasan yang lebih ringan, dan mudah, tidak sedetail tafsir kedua. Tujuanya memang untuk memudahkan pembaca walaupun masih tetap memberikan pembahasan-pembahasan seputar gramatikal dan menjelaskan kata-kata yang dirasa asing di telinga khalayak. 
Tafsir kedua adalah al-Tafsir al-Munir fi al-'Aqidah wa al-Syari'ah wa alManhaj. Kitab ini adalah yang menjadi pembahasan pokok artikel. Penulis bermaksud menyuarakan bahwa sampai saat ini ghirah jihad bil qalam para ulama tafsir masih tidak jauh berbeda dengan para pendahulunya. Kemudian tafsir ketiga adalah Tafsir al-Wajiz, yaitu tafsir yang diperuntukkan bagi kalangan umum.

Al-Tafsir al-Munir fi al-'Aqidah wa al-Syari'ah wa al-Manhaj adalah mahakarya al-Zuhaily dalam bidang tafsir. Sebagaimana ia juga memiliki mahakarya dalam bidang fiqih yang berjudul al-Fiqh al-Islamy wa Adillatuhu, dan hakikatnya, gelar doktor yang ia terima adalah dalam bidang fiqih, namun bukan di sini tempat pembahasannya.

Al-Tafsir al-Munir fi al-'Aqidah wa al-Syari'ah wa al-Manhaj adalah kitab tafsir yang sangat besar terdiri dari-kurang lebih-sembilan ribu halaman, terdiri darikurang lebih-tiga puluh dua bagian dan tujuh belas jilid besar. Setiap jilid-kurang lebih-berisi dua juz pembahasan ayat-ayat al-Qur'an. Tak berlebihan kiranya kalau penulis katakan bahwa kitab ini adalah semacam buku ensiklopedia (al-Mausu'ah). ${ }^{10}$

Pada jilid pertama, al-Zuhaily menghidangkan kepada pembaca tentang diskursus-diskursus penting terkait ilmu al-Qur'an, seperti; definisi al-Qur'an, bagaimana turunnya al-Qur'an, bagaimana sejarah kodifikasinya, tentang cara penulisan awal al-Qur'an, tentang rasm al-Utsmany, pengetahuan tentang al-Ahruf al-Sab'ah dan al-Qira'at al-Sab 'u, tentang aneka ragam mukjizat yang dikandung alQur'an, membahas bahasa al-Qur'an; terjemah dan hukumnya, membicarakan hurufhuruf muqatta'ah pada setiap awal surat dan pendapat para ulama tentangnya, dan juga membahas ilmu-ilmu sastra (balagah) seperti; tasybih, al-Isti'arah, al-Majaz, al-Kinayah di dalam al-Qur'an.

Di dalam tafsirnya, al-Zuhaily tidak sedikit mengutip kitab-kitab tafsir terdahulu seperti; Jami'u al-Bayan fi Tafsir al-Qur'an li al-Thabary, Tafsir Ibn Katsir, Fath al-Qadir li al-Syaukany, al-Jawahir al-Hisan fi Tafsir al-Qur'an li alTsa'aliby, Mafatih al-Gaib li al-Razy, al-Bahr al-Muhith li Ibn Hayyan al-Andalusy, Garaib al-Qur'an wa Ragaib al-Furqan li Muhammad bin al-Husain al-Khurasany al-Naisabury, Ruh al-Ma'any li al-Alusy, Tafsir al-Baidlawy, Tafsir al-Nasafy, Tafsir

\footnotetext{
${ }^{10}$ Muhammad 'Arif Ahmad Fari', Manhaj Wahbah al-Zuhaily fi Tafsirihi li al-Qur'an "al-Tafsir alMunir", 28.
} 
al-Jalalain, Tafsir al-Khazin, Tafsir Aby Su'ud, Ahkam al-Qur'an li al-Jashshas, Ahkam al-Qur'an li Ibn al-'Araby, Tafsir al-Manar, al-Jawahir fi Tafsir al-Qur'an li Thanthawy Jauhary, Tafsir al-Maragy, Fi Zilal al-Qur'an li Sayyid Qutb.

Al-Tafsir al-Munir fi al- 'Aqidah wa al-Syari'ah wa al-Manhaj, judul tafsir ini membawa tiga term besar; 'aqidah, syari'ah, dan manhaj. Itu berarti bahwa alZuhaily memberikan perhatian khusus terhadap ketiganya, bahwa yang hendak ditonjolkan di dalam tafsirnya adalah seputar akidah, syari'ah, dan manhaj (pedoman).

Dalam hal akidah, al-Zuhaily meneruskan pemahaman ulama' ahlussunnah wal jama'ah perihal masalah-masalah teologis seperti; al-Asma' wa al-shifat, af'al al-'ibad, al-istiwa' 'ala al- 'arsy, al-qada' wa al-qadr, al-masyi'ah (al-Iradah), alyaum al-akhir, al-ba'ts (kiamat), al-Jaza' (pembalasan), al-hisab (penghitungan amal). Dalam diskursus tersebut, al-Zuhaily memperkuat penafsirannya dengan merujuk kepada penafsiran ulama' ahlussunnah wal jama'ah, baik salaf maupun khalaf. $^{11}$

Dalam hal syari'ah merupakan sesuatu yang tidak perlu diragukan lagi bahwa al-Zuhaily sejak awal perjalanan pendidikannya memang mengambil konsentrasi ilmu syari'ah. Kematangan ilmunya dalam bidang syari'ah ia buktikan dengan karya besarnya yang berjudul "al-Fiqh al-Islamy wa Adillatuhu”, sebuah ensiklopedia fiqih yang memuat kajian-kajian fiqih lengkap dan mencakup hampir seluruh permasalahan fikih baik klasik ataupun kontemporer.

Maksud dari manhaj adalah pedoman, jalan, ataupun cara. Dengan karya tafsirnya, Al-Zuhaily hendak mengabarkan bahwa Islam mengajak manusia menuju cara hidup yang sehat secara keseluruhan, dengan kata lain bahwa Islam adalah agama yang mengajak manusia menuju kesucian jati diri (fitrah). Hal itu sebagaimana disebutkan oleh al-Zuhaily di dalam mukaddimah tafsirnya bahwa niat itulah yang menjadi salah satu alasan mendasar baginya dalam menulis sebuah kitab tafsir al-Qur'an.

\footnotetext{
${ }^{11}$ Muhammad 'Arif Ahmad Fari', Manhaj Wahbah al-Zuhaily fi Tafsirihi li al-Qur'an "al-Tafsir alMunir", 99.
} 


\section{Metode Tafsir Wahbah Al-Zuhaily}

\section{Ditinjau dari sumber penafsirannya}

Kalau penulis meminjam istilah yang dikenalkan oleh Muhammad Ridlwan Nasir, maka metode yang digunakan Wahbah al-Zuhaily dalam tafsirnya adalah metode iqtiran. Artinya, metode yang digunakan adalah dengan menggunakan sumber riwayat yang sahih dan juga menggunakan sumber akal yang sarih. Maksudnya, dalam menafsirkan ayat-ayat al-Qur'an, al-Zuhaily tidak hanya menggunakan informasi dari hadist-hadist nabi dan riwayat para sahabat serta tabi' in (tafsir bi al-ma'tsur) namun juga menyuguhkan tafsir bi al-ra'y.

Al-Zuhaily-di dalam tafsirnya-tidak jarang mengutip penafsiran al-Razy. Sebagaimana telah dikenal para cendikiawan bahwa dalam bidang tafsir al-Qur'an, ilmu kalam, dan ilmu mantiq, pemikiran al-Razy sangatlah dipertimbangkan bahkan dikagumi. Tidak jarang al-Zuhaily setelah menjelaskan satu pembahasan, ia memperkuat argumentasinya dengan mengutip langsung pendapat al-Razy. Seperti ketika menjelaskan surat al-Nisa' ayat 171 .

\section{Ditinjau dari segi cara penjelasannya terhadap ayat-ayat al-Qur'an}

Tafsir ini menjelaskan ayat-ayat al-Qur'an secara deskripsi. Artinya, metode yang digunakan dalam menjelaskan ayat-ayat al-Qur'an adalah metode bayani yaitu menjelaskan dengan memberikan keterangan secara deskripsi tidak dengan menonjolkan komparasi/perbandingan terhadap penafsiran tokoh tertentu.

\section{Ditinjau dari keluasan tafsirnya}

Pada tafsir ini, Al-Zuhaily menerapkan metode ithnaby, artinya menafsirkan al-Qur'an dengan terperinci dan detail, dengan penjelasan yang cukup panjang bukan penjelasan secara global. Walaupun pada awal pembahasan surat dipaparkan juga pesan yang dikandung oleh surat dengan penjelasan yang global. Hal itu bukan berarti ia menggunakan metode ijmaly, karena setelah itu ia melanjutkan penjelasannya secara panjang lebar.

Di dalam tafsir al-Zuhaily, pembaca akan mendapati penjelasan-penjelasan seperti; tentang makkiyah dan madaniyah, jumlah ayat surat yang dibahas, 
menjelaskan sebab penamaan suratnya (di sebagian surat), menjelaskan korelasi (munasabah) dengan surat sebelumnya, memaparkan hukum-hukum yang terkandung di dalam surat yang dikaji, menyebutkan tentang fadail (keutamaan) yang dimiliki surat atau ayat yang sedang dibahas, membahas i'rab (gramatikal) ayat-ayat yang sedang dibahas dengan menyertakan ragam perbedaan qiraat, dan menyebutkan sisi sastra yang terdapat di dalam ayat-ayat yang sedang dibahas, dan memberikan pemahaman tentang kehidupan serta hukum-hukum yang diisyaratkan oleh ayat-ayat atau bagian yang sedang dibahas.

\section{Ditinjau dari segi sasaran dan tertib ayat yang ditafsirkan}

Tafsir Wahbah al-Zuhaily (al-Tafsir al-Munir fi al-'Aqidah wa al-Syari'ah wa al-Manhaj) ini jika ditinjau dari segi sasaran dan tertib ayat yang ditafsirkan maka menggunakan metode tahlily, artinya penafsirannya runtut sebagaimana urutan ayat-ayat dalam al-Qur'an, mulai surat al-Fatihah sampai surat al-Nas. Hanya saja, al-Zuhaily memberi sedikit nuansa yang boleh dibilang menyerupai metode maudlu'iy, yaitu menggolongkan ayat-ayat yang runtut itu menjadi satu kesatuan tema pembahasan. Misalnya surat al-Baqarah ayat 1-5 ia golongkan ke dalam tema "sifat-sifat orang-orang beriman dan balasan bagi orang yang bertaqwa", ayat 6-7 "sifat orang-orang kafir, ayat 8-10 "sifat-sifat orang munafik", dan seterusnya.

\section{Corak/Kecenderungan Tafsir Wahbah Al-Zuhaily}

Sebenarnya, judul tafsir al-Zuhaily (al-Tafsir al-Munir fi al-'Aqidah wa alSyari'ah wa al-Manhaj) telah mewakili akan kecenderungan serta corak yang terkandung di dalamnya. Sebagaimana penulis jelaskan pada pembahasanpembahasan sebelumnya, tentang akidah, syari'ah, dan pedoman hidup sama-sama menjadi perhatian di dalam kitabnya. Dengan kata lain bahwa tafsir al-Zuhaily ini merupakan kitab yang boleh jadi memiliki keunikan atau semacam mumayyiz yang membedakan dengan kitab lainnya. Kitab ini sekaligus menyuguhkan tiga corak tafsir; corak 'i'tiqady, corak fiqhy, dan corak ijtima'iy. 


\section{E. PENUTUP}

\section{Kesimpulan}

Al-Tafsir al-Munir fi al-'Aqidah wa al-Syari'ah wa al-Manhaj merupakan sumbangsih yang sangat berharga dalam literatur keislaman. Menurut penulis, kitab ini merupakan salah satu rujukan yang komperhensif dalam studi ilmu al-Qur'an dan tafsir. Selain meneruskan penafsiran para mufassir ahlussunnah wa al-jama'ah terdahulu ia juga menggabungkan penafsiran-penafsiran modern sehingga informasi yang disuguhkan begitu lengkap dan merupakan "angin segar" bagi para pecinta alQur'an.

\section{Saran}

Dengan penuh kerendahan, penulis menyadari bahwa artikel ini merupakan secuil dari informasi yang berserakan tentang Tafsir Wahbah al-Zuhaily. Penulis mengumpulkan informasi tentang Tafsir Wahbah al-Zuhaily ini hanya berdasarkan terbatasnya waktu dan sempitnya ilmu yang dimiliki. Itu sebabnya, kritik dan saran demi menyempurnakan tulisan ini merupakan harapan yang muncul dari lubuk hati penulis. Terlepas dari itu, semoga sedikit informasi ini bisa menjadi sesuatu yang bermanfaat bagi para pembaca.

\section{Daftar Pustaka}

Al-Qur'an al-Karim

Ahmad Fari', Muhammad 'Arif, Manhaj Wahbah al-Zuhaily fi Tafsirihi li al-Qur'an “al-Tafsir al-Munir", ttp: tp, tth.

Fanisan (al), Su'ud ibn 'Abdullah, Ikhtilaf al-Mufassirin; Asbabuhu wa Atsaruhu, Riyad: Dar Syibilya, 1997.

Jathlawy (al), Qadaya al-Lugah fi Kutub al-Tafsir; al-Manhaj, al-Ta'wil, al-'I'jaz, ttp: Dar Muhammad 'Aly al-Hamy, 1998.

Khalid, 'Abdu al-Rahman al-'Ik, Ushul al-Tafsir wa Qawa'iduhu, Beirut: Dar alNafa'is, 1986.

Khalifah, Ibrahim Abdu al-Rahman, Dirasat fi Manahij al-Mufassirin, Cairo: ttp, tth.

Muhammad Salih, 'Abd al-Qadir, al-Tafsir wa al-Mufassirun fi al-'Ashr al-Hadits, Beirut: Dar al-Ma'rifah, 2003.

Munawwir, Ahmad Warson, al-Munawwir Kamus Arab-Indonesia, Surabaya: Pustaka Progresif, 1997. 
Muhammad (al-Sayyid), 'Aly Iyazy, al-Mufassirun Hayatuhum wa Manhajuhum, ttp: Muassasat al-Thaba'ah wa al-Nasyr Wizarat al-Tsaqafah wa al-Irsyad al-Islamy: tth.

Nasir, Muhammad Ridlwan, Teknik Pengembangan Metode Tafsir Muqarin, t.p.: 2997.

Sayyid 'Aly (al), Mahmud al-Naqrasyi, Manahij al-Mufassirin min al-'Ashr al-Awwal ila al-'Ashr al-Hadist, Maktabah al-Nahdlah.

Shobag (al), Muhammad bin Luthfi, Lamhat fi 'Ulum al-Qur'an wa Ittijahat al-Tafsir, Beirut: al-Maktabah al-Islamy, 1990, 260.,

Subhany (al), Ja'far, al-Manahij al-Tafsiriyyah fi 'Ulum al-Qur'an,Iran: Muassasah alImam al-Shadiq, $1432 \mathrm{H}$.

Suyuthy (al), al-Itqan fi'Ulum al-Qur'an, Beirut: Dar al-Fikr, 2008.

Taimiyyah (ibn), Muqaddimat fi Ushul al-Tafsir, ttp: tp, 1972.

Zahaby (al), Muhammad Husain, al-Tafsir wa al-Mufassirun, Cairo: Maktabah Wahbah, 2000.

Zahaby (al), Muhammad Husain, 'Ilm al-Tafsir, Cairo: Dar al-Ma'arif, t.t.

Rumy (al), Fahd bin 'Abdu al-Rahman bin Sulaiman, Manhaj al-Madrasah al'Aqliyyah al-Haditsah fi al-Tafsir, Riyad: tp, 1983. 